\title{
Pengaruh Good Corporate Governance terhadap Corporate Social Responsibility pada Perusahaan Sub Sektor Transportasi
}

\section{The Effect of Good Corporate Governance on Corporate Social Responsibility in Companies in the Transportation Sub Sector}

\author{
Noriko Thasya ${ }^{1)}$, Lisah $^{2)}$, Angeline $^{3)}$, Natasyah Gozal $^{4)}$, Veronica $^{5)}$, Namira Ufrida Rahmi ${ }^{6)}$ \\ ${ }^{1,2,3,4,5,6)}$ Fakultas Ekonomi, Universitas Prima Indonesia, Kota Medan \\ e-mail korespondensi: norikothasya@gmail.com
}

\begin{tabular}{|c|c|}
\hline Info & \multirow{4}{*}{$\begin{array}{l}\text { Abstrak } \\
\text { Penelitian ini bertujuan untuk menguji pengaruh Good Corporate Governance } \\
\text { terhadap Corporate Sosial Responsibility (CSR). Populasi yang digunakan } \\
\text { adalah perusahaan sub sektor transportasi yang terdaftar di Bursa Efek Indonesia } \\
\text { periode } 2014-2018 \text { yang berjumlah } 37 \text { perusahaan. Purposive sampling } \\
\text { digunakan untuk memperoleh delapan perusahaan yang dijadikan sampel } \\
\text { penelitian. Data yang digunakan dalam bentuk laporan tahunan yang diterbitkan } \\
\text { oleh perusahaan-perusahaan tersebut, dan dianalisis menggunakan analisis } \\
\text { regresi linier berganda. Hasil penelitian ini menunjukkan bahwa secara simultan, } \\
\text { Komite Audit, Dewan Komisaris, Kepemilikan Institusional dan Komisaris } \\
\text { Independen terbukti berpengaruh secara signifikan terhadap CSR. Namun } \\
\text { demikian, hasil pengujian statistik secara parsial membuktikan bahwa Komite } \\
\text { Audit dan Kepemilikan Institusional secara signifikan berpengaruh negatif } \\
\text { terhadap CSR; Dewan Komisaris berpengaruh secara positif dan signifikan } \\
\text { terhadap CSR; serta Komisaris Independen memiliki pengaruh negatif tetapi } \\
\text { tidak signifikan terhadap CSR. } \\
\text { Kata Kunci: Good Corporate Governance, Komite Audit, Dewan Komisaris, } \\
\text { Kepemilikan Institusional, Komisaris Independen, Corporate Sosial } \\
\text { Responsibility. }\end{array}$} \\
\hline $\begin{array}{l}: \\
\text { ovember } 2019 \\
\text { esember } 2019 \\
\text { Januari } 2020\end{array}$ & \\
\hline $\begin{array}{l}I \\
\text { seb.v11i1.1764 }\end{array}$ & \\
\hline & \\
\hline
\end{tabular}

\begin{tabular}{|c|c|}
\hline & \\
\hline & $\begin{array}{l}\text { This study aims to examine the effect of Good Corporate Governance on } \\
\text { Corporate Social Responsibility (CSR). The population used is the } \\
\text { transportation sub-sector companies listed on the Indonesia Stock Exchange } \\
\text { period } 2014-2018 \text {, amounting to } 37 \text { companies. Purposive sampling was used }\end{array}$ \\
\hline $\begin{array}{l}\text { Good } \\
\text { ee } \\
\text { ocial }\end{array}$ & $\begin{array}{l}\text { to obtain } 8 \text { companies as research samples. Data used in the form of annual } \\
\text { reports published by the companies, and analyzed using multiple linear } \\
\text { regression. The results indicate that simultaneously, Audit Committee, the } \\
\text { Board of Commissioners, Institutional Ownership and Independent } \\
\text { Commissioners prove to have a significant effect on CSR. However, the results } \\
\text { of statistical tests prove that partially, the Audit Committee and Institutional } \\
\text { Ownership have a significant negative effect on CSR; The Board of } \\
\text { Commissioners has positive and significant influence on CSR; and Independent } \\
\text { Commissioners have a negative but not significant effect on CSR. }\end{array}$ \\
\hline 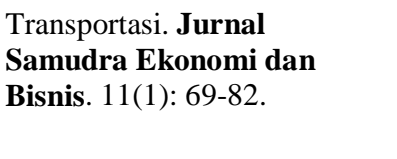 & $\begin{array}{l}\text { Keywords: Good Corporate Governance, Audite Committee, Board of } \\
\text { Commissioners, Institutional Ownership, Independent Commissioner, } \\
\text { Corporate Sosial Responsibility. }\end{array}$ \\
\hline
\end{tabular}




\section{PENDAHULUAN}

Indonesia adalah negara kepulauan yang terdiri dari 17.504 pulau. Suatu negara yang memiliki perekomian yang baik pasti didukung dengan tingkat pembangunan infrastruktur yang baik salah satunya yaitu sector transportasi. Sektor transportasi di Indonesia merupakan pelayanan jasa dan sumber utama dalam kegiatan ekonomi yang pada akhirnya akan menentukan tingkat kualitas daya saing suatu perekonomian, tersedianya sarana dan prasarana yang memadai, layak, efektif, efesien dan berkembangnya industri jasa pada sector transportasi darat, laut dan udara akan menentukan kecepatan pertumbuhan perekonomian Indonesia untuk mengatasi pesaingan global yang semakin tinggi. Perkembangan perusahaan senantiasa dihadapkan pada tanggung jawab yang berpijak pada tiga garis dasar, yaitu ekonomi, sosial khususnya kesejahteraan masyarakat dan pemeliharan serta pelestarian lingkungan (Siagian, 2010).

Indonesia adalah negara berkembang yang diharapkan tahun ke tahun dapat semakin berkembang hingga pada tahap dikatakan negara maju. Oleh sebab itu, diharapkan dalam membantu pembangunan perekonomian, para stakeholder, yaitu pemerintah, dunia usaha dan masyarakat untuk dapat saling menguntungkan, saling berkontribusi dan dapat memiliki hubungan yang harmonis (Setyarini \& Paramitha, 2011). Dalam hal ini, dunia usaha memegang peran yang sangat penting dalam sistem ekonomi dengan cara turut berpartisipasi dalam kegiatan sosial maupun kegiatan apapun yang bertujuan untuk mengembangkan lingkungan, meningkatkan dan membangun perekonomian serta mensejahterahkan kehidupan masyarakat agar lebih baik lagi, atau dapat disebutkan dengan Corporate Social Responsibility (CSR).
Seperti halnya ditetapkan dalam UU No. 40 Tahun 2007 tentang Perseroan Terbatas Pasal 74, bahwa pihak perseroan wajib melaksanakan tanggungjawab sosial serta lingkungan, dan jika perusahaan tersebut tidak melaksanakannya maka akan diberi sanksi sesuai dengan peraturan perundangundangan. CSR atau Tanggungjawab Sosial yang dibebankan pada perusahaan adalah suatu program kepedulian dari perusahaan terhadap masyarakat dan lingkungan sekitar, kontribusi yang diberikan dapat mendorong pemberdayaan masyarakat.

Keterlibatan sosial perusahaan ini sangatlah diharuskan, dikarenakan melalui program ini dapat mendapatkan berbagai keuntungan baik bagi pihak perusahaan maupun masyarakat, seperti dalam hal mendapat citra positif dari masyarakat. Dengan melaksanakan program CSR, maka perusahaan dapat memperoleh keuntungan jangka panjang, ataupun dalam hal terbangkitkannya kesadaran dari perusahaan akan pentingnya lingkungan sosial yang baik. Lingkungan sosial yang baik akan dapat mendukung keberhasilan bisnis untuk waktu yang panjang (Keraf, 1998).

\section{Komite Audit}

Komite audit ialah salah satu indikator good corporate governance. Dewan komisaris dapat membentuk komite audit sebagai bagian terpisah dan bertanggungjawab terhadap pengawasan secara menyeluruh. Pengawasan secara menyeluruh terhadap kredibilitas pelaporan keuangan dan tata kelola perusahaan (Bradbury et al., 2004). Dalam menjalankan tugas komite audit, diperlukan adanya independensi atau tidak mudah dipengaruhi.

Sejumlah penelitian terdahulu memperoleh hasil yang berbeda berkaitan dengan pengaruh dari komite audit terhadap CSR. Hasil-hasil penelitian milik Wiyuda dan 
Pramono (2017), Prastuti dan Budiasih (2015), Yusran et al. (2018) serta Fatimah et al. (2016) menemukan bahwa Corporate Social Responsibility dipengaruhi oleh komite audit. Sebaliknya, hasil-hasil empiris yang diperoleh Sanjaya et al. (2014), Terzaghi (2012), Paramita dan Marsono (2014) serta Untoro dan Zulaikha (2013) menemukan bahwa komite audit tidak mempengaruhi Corporate Sosial Responsibility.

Berdasarkan hasil telaah atas teori dan penelitian terdahulu mengenai hubungan antara komite audit dan CSR, dimunculkan hipotesis pertama dalam penelitian ini sebagai berikut.

H1 : Komite audit berpengaruh secara parsial terhadap pengungkapan Corporate Social Responsibility.

\section{Dewan Komisaris}

Dewan Komisaris adalah sekelompok orang yang bertugas melakukan pengawasan kegiatan perusahaan dan memberi nasihat kepada direktur perusahaan. Umumnya dewan komisaris terdapat di Perseroan terbatas (PT) (Amanti, 2012). Semakin besar jumlah anggota dewan komisaris maka upaya pengendalian atas pemimpin perusahaan dan aktivitas monitoring yang dilakukan akan semakin efektif (Coller \& Gregory, 1999).

Berhubungan dengan pengaruh dari ukuran dari dewan komisaris terhadap CSR, penelitian-penelitian terdahulu memperoleh hasil yang berbeda. Hasil-hasil penelitian milik Wiyuda dan Pramono (2017), Yusran et al. (2018), Untoro dan Zulaikha (2013), Ramadhaningsih dan Utama (2013) serta Nugroho (2016) menemukan Corporate Social Responsibility dipengaruhi oleh ukuran atau jumlah dari dewan komisaris perusahaan. Sebaliknya hasil-hasil penelitian dari Sari et al. (2013), Terzaghi (2012), Paramitha dan Marsono (2014) serta Hutapea dan Malau (2018) menemukan bahwa Corporate Social
Responsibility tidak dipengaruhi oleh ukuran dewan komisaris.

Berdasarkan hasil telaah atas teori dan penelitian terdahulu mengenai hubungan antara ukuran dewan komisaris dan CSR, dimunculkan hipotesis kedua dalam penelitian ini sebagai berikut.

H2 : Ukuran Dewan Komisaris berpengaruh secara parsial terhadap pengungkapan Corporate Social Responsibility.

\section{Kepemilikan Institusional}

Kepemilikan institusional merupakan kepemilikan saham dari institusi lainnya (Rustiarini, 2010). Biasanya institusi memiliki kepemilikan saham yang besar dibandingkan dengan pemegang saham lainnya, sehingga dapat melakukan kontrol terhadap kebijakan manajemen suatu perusahaan secara lebih kuat dibandingkan para pemegang saham lainnya. Dengan tingginya level kepemilikan institusional maka bisa menimbulkan upaya pengawasan yang lebih besar dan ketat sehingga dapat mencegah dan mengurangi perilaku yang merugikan atau perilaku yang menyimpang (Shleifer \& Vishny, 1986).

Sejumlah penelitian terdahulu memperoleh hasil yang berbeda berkaitan dengan pengaruh kepemilikan institusional terhadap CSR. Hasil-hasil penelitian milik Setyarini dan Paramitha (2011), Sanjaya et al. (2014), Prastuti dan Budiasih (2015) serta Sari et al. (2013) mengidentifikasi bahwa Corporate Sosial Responsibility dipengaruhi oleh kepemilikan institusional. Namun demikian, hasil-hasil studi empiris yang diperoleh Nilasari (2015) serta Terzaghi (2012) menyatakan Corporate Sosial Responsibility tidak dipengaruhi oleh besaran kepemilikan institusional.

Berdasarkan hasil telaah atas teori dan penelitian terdahulu mengenai hubungan antara besaran kepemilikan institusional dan 
CSR, dimunculkan hipotesis ketiga dalam penelitian ini sebagai berikut.

H3 : Kepemilikan Institusional berpengaruh secara parsial terhadap pengungkapan Corporate Social Responsibility.

\section{Komisaris Independen}

Komisaris Independen adalah dewan komisaris yang berasal dari luar perusahaan, tidak mempunyai saham, serta tidak memiliki hubungan afiliasi maupun hubungan usaha yang berkaitan dengan perusahaan (Rachmad, 2013).

Sejumlah penelitian terdahulu memperoleh hasil-hasil empiris yang berbeda berkaitan dengan pengaruh dari ukuran dari komisaris independen terhadap CSR. Hasilhasil penelitian milik Setyarini dan Paramitha (2011), Terzaghi (2012), Fatimah et al. (2016) serta Ramadhaningsih dan Utama (2013) menyatakan bahwa komisaris Independen memiliki pengaruh terhadap Corporate Sosial Responsibility. Sebaliknya, hasil-hasil empiris yang diperoleh Sanjaya et al. (2014), Prastuti dan Budiasih (2015), Paramita dan Marsono (2014) serta Untoro dan Zulaikha (2013) mengidentifikasi komisaris independen tidak memberikan pengaruh terhadap Corporate Sosial Responsibility.

Berdasarkan hasil telaah atas teori dan penelitian terdahulu mengenai hubungan antara ukuran dari komisaris independen dan CSR, dimunculkan hipotesis keempat dalam penelitian ini sebagai berikut.

H4 : Komisaris Independen berpengaruh secara parsial terhadap pengungkapan Corporate Social Responsibility.

Lebih jauh, penelitian melakukan analisis atas pengaruh simultan dari keempat variabel independen yang diteliti, yaitu komite audit, dewan komisaris, kepemilikan institusional dan komisaris independen, terhadap Corporate Social Responsibility. Dalam proses pengujian pengaruh tersebut, dimunculkan hipotesis kelima dari penelitian ini sebagai berikut.

H5 : Komite Audit, Dewan Komisaris, Kepemilikan Institusional dan Komisaris Independen memiliki pengaruh secara simultan terhadap pengungkapan Corporate Social Responsibility.

\section{METODE PENELITIAN}

\section{Populasi dan Sampel}

Populasi dalam penelitian ini adalah seluruh perusahaan sub sektor transportasi yang terdaftar di Bursa Efek Indonesia (BEI) yang berjumlah 37 perusahaan. Sampel penelitian diseleksi menggunakan metode purposive sampling, yaitu teknik penentuan sampel dengan kriteria tertentu (Hasan. 2004). Kriteria yang digunakan untuk menyeleksi sampel adalah: (1) Perusahaan sub sektor transportasi yang terdaftar di BEI tahun 20142018; (2) Perusahaan Perusahaan sub sektor transportasi yang konsisten mempublikasikan laporan tahunan (annual report) dari tahun 2014-2018; (3) Perusahaan sub sektor transportasi yang menggunakan mata uang rupiah. Berdasarkan kriteria tersebut, terpilih 8 perusahaan menjadi sampel penelitian ini.

\section{Metode Pengumpulan Data}

Metode pengumpulan data pada penelitian ini dilakukan dengan menggunakan metode studi dokumentasi, yaitu menggunakan laporan tahunan yang dipublikasikan di Bursa Efek Indonesia, dan data yang berhubungan dengan variabel-variabel dalam penelitian ini. Dalam penelitian ini jenis data yang digunakan adalah data sekunder, yaitu laporan tahunan perusahaan transportasi yang terdaftar di Bursa Efek Indonesia periode 2014-2018. Data sekunder diperoleh dari situs www.idx.co.id. 


\section{Definisi Operasional Variabel}

Penelitian ini menggunakan empat variabel independen dan satu variabel dependen. Variabel independen meliputi komite audit, dewan komisaris, kepemilikan institusional serta komisaris independen. Variabel dependen adalah Corporate Social Responsibility. Definisi operasional dari masing-masing variabel itu adalah sebagai berikut.

\section{Komite Audit}

Komite audit dibentuk oleh dewan komisaris, yang memiliki tugas membantu menjalankan tugas dewan komisaris. Ukuran komite audit diukur dengan menghitung jumlah anggota komite audit dalam laporan tahunan perusahaan yang tercantum pada laporan tata kelola perusahaan (Waryanto, 2010). Pengukuran untuk komite audit adalah jumlah keseluruhan dari anggota komite audit milik perusahaan.

\section{Dewan Komisaris}

Dewan komisaris bertugas mengawasi manajemen dalam mengelola perusahaan, terjaminnya pelaksaan strategi perusahaan serta terlaksananya akuntabilitas. Dewan komisaris dapat dikatakan pula sebagai wakil dari para investor atau pemilik perusahaan untuk mengawasi pengelolaan perusahaan yang dilaksanakan manajemen (Pasaribu et al., 2015). Pengukuran untuk dewan komisaris adalah jumlah keseluruhan dari anggota dewan komisaris yang berada di dalam perusahaan.

\section{Kepemilikan Institusional}

Kepemilikan institusional adalah jumlah saham yang dimiliki oleh suatu institusi keuangan seperti perusahaan asuransi, bank, investasi, atau institusi lain-lain (Rustiarini, 2010). Dalam kepemilikan institusional dilakukan pengecualian atas anak perusahaan dan institusi yang memiliki hubungan istimewa (afiliasi dan asosiasi). Pengukuran untuk kepemilikan institusional adalah rasio perbandingan antara proporsi jumlah saham yang dimiliki pihak institusional dengan jumlah keseluruhan saham perusahaan yang beredar di pasar modal.

\section{Komisaris Independen}

Komisaris independen adalah anggota dewan komisaris yang tidak memiliki ikatan bisnis atau hubungan keluarga dengan direksi maupun anggota dewan komisaris lainnya (Rachmad, 2013). Pengukuran untuk komisaris independen adalah rasio perbandingan antara jumlah anggota komisaris independen dengan jumlah seluruh anggota dari dewan komisaris perusahaan.

\section{Corporate Social Responsibility}

Corporate Social Responsibility (CSR) adalah tanggungjawab perusahaan dengan memberikan kepedulian serta perhatian terhadap lingkungan social. Penelitian ini menggunakan item CSR yang diterbitkan oleh Global Reporting Initiative (GRI) yang berjumlah 91 item pengungkapan. Apabila item CSR ada dalam laporan tahunan maka diberi nilai 1 , dan sebaliknya apabila tidak ada diungkapkan maka akan diberi nilai 0 . Indeks pengungkapan tanggungjawab social perusahaan adalah rasio perbandingan antara penjumlahan dari seluruh item-item CSR berdasarkan Global Reporting Initiative (GRI) yang terdapat di dalam laporan tahunan perusahaan dibagi dengan total item keseluruhan (Sayekti \& Wondabio, 2007).

\section{Metode Analisis Data}

Metode analisis data dalam penelitian ini adalah regresi linier berganda, dan pengolahan data dibantu menggunakan program SPSS (Statistical Product and Service Solutions) versi 25. Regresi linier berganda yaitu teknik analisis yang mengukur pengaruh beberapa variabel bebas terhadap 
variabel terikat. Bentuk persamaan yang digunakan dalam penelitian ini adalah:

$$
\mathrm{Y}=\alpha+\beta_{1} \mathrm{X}_{1}+\beta_{2} \mathrm{X}_{2}+\beta_{3} \mathrm{X}_{3}+\beta_{4} \mathrm{X}_{4}+\mathrm{e}
$$

dimana $\mathrm{Y}$ adalah indeks skor pengungkapan CSR; $\alpha$ adalah Konstanta; $\beta$ adalah koefisien regresi dari variabel independen; $\mathrm{X}_{1}$ adalah Komite Audit; $\mathrm{X}_{2}$ adalah Dewan Komisaris; $\mathrm{X}_{3}$ adalah Kepemilikan Institusional; $\mathrm{X}_{4}$ adalah Komisaris Independen; dan $e$ adalah error term.

Tahap selanjutnya adalah melakukan uji hipotesis. Pengujian hipotesis pada penelitian ini menggunakan uji t, uji $\mathrm{F}$ dan koefisien determinasi. Pengujian menggunakan level signifikansi sebesar $0,05(\alpha=5 \%)$. Pada uji $t$, hipotesis bersifat parsial ( $\mathrm{H} 1, \mathrm{H} 2, \mathrm{H} 3$ dan $\mathrm{H} 4)$ dinyatakan terbukti atau diterima apabila hasil pengolahan statistik menyatakan bahwa nilai signifikansi $t$ adalah lebih kecil dari $\alpha$ (Sig. $\mathrm{t}$ $<0,05)$. Pada uji $F$, hipotesis bersifat simultan (H5) dinyatakan terbukti atau diterima apabila hasil pengolahan statistik menyatakan bahwa nilai signifikansi $F$ adalah lebih kecil dari $\alpha$ (Sig. F < 0,05). Analisis koefisien determinasi dilakukan berdasarkan nilai Adjusted R2, dimana semakin besar nilai itu menunjukkan semakin besar kemampuan variabel-variabel independen yang dicakup dalam model penelitian menjelaskan perubahan-perubahan yang terjadi pada variabel dependen.

\section{HASIL ANALISIS}

\section{Uji Asumsi Klasik}

Uji asumsi klasik bertujuan memastikan bahwa persamaan regresi yang dihasilkan memiliki ketepatan dalam tidak bias, estimasi, serta konsisten. Hasil pengujian dijabarkan berikut ini.

Uji normalitas dilakukan dengan tiga cara, yaitu uji histogram, uji P-P Plot dan uji Kolmogorov-Smirnov. Berdasarkan hasil uji histogram (Gambar 1), diperoleh bahwa garis kurva cenderung simetris (U), sehingga dapat dikatakan bahwa data berdistribusi normal. Selain itu, hasil uji P-P Plot (Gambar 2) juga menunjukkan titik-titik menyebar mendekati garis diagonal, sehingga dapat dikatakan data berdistribusi normal. Hasil uji KolmogorovSmirnov (Tabel 1) memperoleh nilai Asymp Sig. (2-tailed) sebesar 0,810>0,05, dimana ini berarti data berdistribusi normal. Dengan demikian, ketiga hasil uji normalitas tersebut menyatakan data penelitian berdistribusi normal dan memenuhi asumsi normalitas.

Berikutnya, berdasarkan hasil uji multikolinieritas (Tabel 2), diperoleh nilai Tolerance dari $\mathrm{X}_{1}$ sebesar 0,941>0,1 dengan nilai VIF sebesar 1,063 < 10; nilai Tolerance dari $\mathrm{X}_{2}$ sebesar 0,906 > 0,1 dengan nilai VIF sebesar 1,104 < 10; nilai Tolerance dari $\mathrm{X}_{3}$ sebesar 0,738>0,1 dengan nilai VIF sebesar 1,354 < 10; dan, nilai Tolerance dari $\mathrm{X}_{4}$ sebesar 0,751>0,1 dengan nilai VIF sebesar $1,331<10$. Hasil analisis atas nilai Tolerance maupun VIF tersebut menunjukkan tidak terdapat multikolinieritas antar variabel independen di dalam model penelitian ini.

Berdasarkan Tabel 3, hasil uji Glejser menunjukkan nilai signifikansi dari masingmasing variabel independen $\left(\mathrm{X}_{1}=0,198 ; \mathrm{X}_{2}=\right.$ 0,$\left.485 ; X_{3}=0,919 ; X_{4}=0,420\right)$ lebih besar dari 0,05 . Selain itu, dari grafik scatterplot (Gambar 3) terlihat bahwa titik-titik menyebar secara acak tanpa pola yang jelas di atas dan dibawah angka nol (0). Dengan demikian, dapat dinyatakan tidak terjadi masalah heteroskedastisitas dalam model penelitian ini.

Hasil uji autokorelasi (Tabel 4) menunjukkan nilai Durbin-Watson (DW) sebesar 1.820 sedangkan dalam tabel DW pada taraf nyata $5 \%(\mathrm{k}=4 ; \mathrm{n}=40)$ maka didapatkan nilai $\mathrm{d}_{\mathrm{L}}=1,2848$ dan $\mathrm{d}_{\mathrm{U}}=1,7209$. Berdasarkan kriteria $\mathrm{d}_{\mathrm{U}}<\mathrm{DW}<4-\mathrm{d}_{\mathrm{U}}$ atau $1,7209<1,820<2,2791$ maka dinyatakan tidak terdapat autokorelasi dalam persamaan regresi dari penelitian ini. 


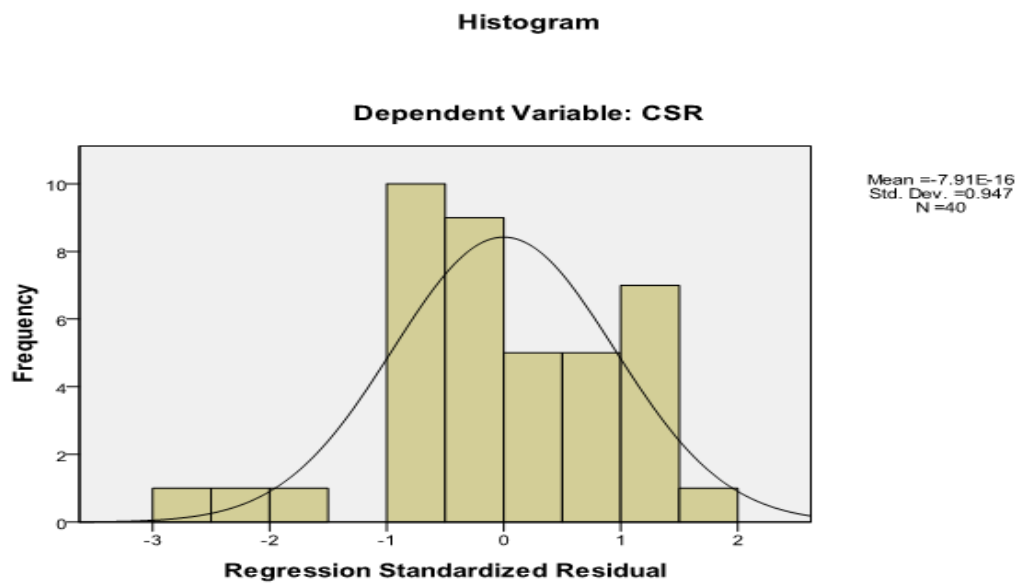

\section{Gambar 1. Hasil Uji Histogram}

Sumber: Data sekunder diolah, 2019.

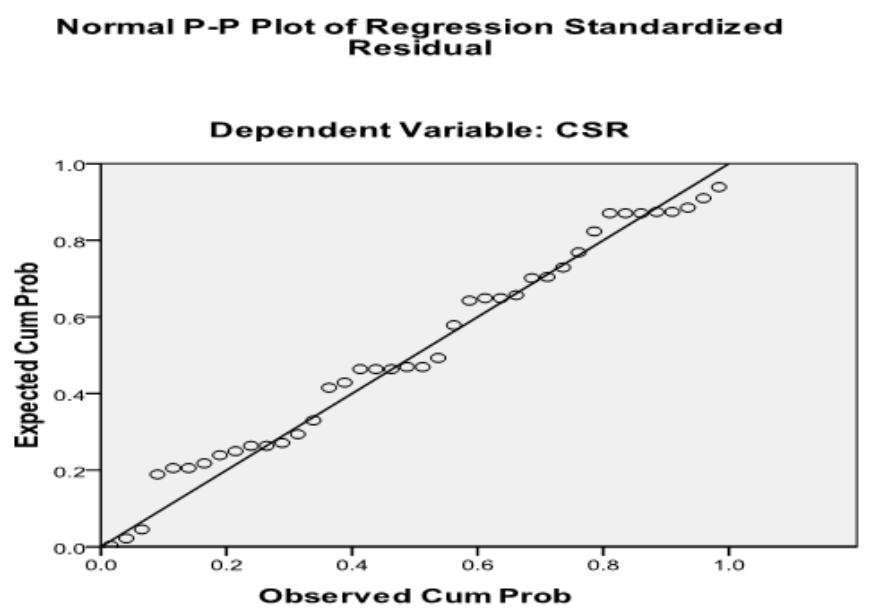

Gambar 2. Hasil Uji P-P Plot

Sumber: Data sekunder diolah, 2019.

Tabel 1. Hasil Uji Kolmogorov-Smirnov

One-Sample Kolmogorov-Smirnov Test

\begin{tabular}{llr}
\hline & & Unstandardized Residual \\
\hline $\mathrm{N}$ & & 40 \\
Normal Parameters ${ }^{\mathrm{a}, \mathrm{b}}$ & Mean & .0000000 \\
& Std. Deviation & .04596766 \\
Most Extreme Differences & Absolute & .101 \\
& Positive & .057 \\
& Negative & -.101 \\
Kolmogorov-Smirnov Z & & .638 \\
Asymp. Sig. (2-tailed) & & .810 \\
\hline
\end{tabular}

a. Test distribution is Normal.

b. Calculated from data.

Sumber: Data sekunder diolah, 2019. 
Tabel 2. Hasil Uji Multikolinieritas

\begin{tabular}{llcccc}
\multicolumn{7}{c}{ Coefficients $^{\mathbf{a}}$} \\
\multirow{2}{*}{ Model } & \multicolumn{2}{c}{ Unstandardized Coefficients } & \multicolumn{2}{c}{ Collinearity Statistics } \\
\cline { 2 - 5 } & (Constant) & B & Std. Error & Tolerance & VIF \\
\hline Komite_audit & .425 & .076 & & \\
& Dewan_komisaris & .081 & .030 & .941 & 1.063 \\
& Kepemilikan_inst & .007 & .004 & .906 & 1.104 \\
& -.002 & .000 & .738 & 1.354 \\
& Komisaris_independen & .000 & .001 & .751 & 1.331
\end{tabular}

a. Predictors: (Constant), Komisaris_independen, Dewan_komisaris, Komite_audit, Kepemilikan_inst

Sumber: Data sekunder diolah, 2019.

Tabel 3. Hasil Uji Glejser

\section{Coefficients $^{\mathrm{a}}$}

\begin{tabular}{llccccc}
\hline \multirow{2}{*}{ Model } & \multicolumn{2}{l}{ Unstandardized Coefficients } & Standardized Coefficients & & \multirow{2}{*}{ Sig. } \\
\cline { 2 - 5 } \multicolumn{1}{l}{1} & B & Std. Error & Beta & & .946 & .351 \\
& Konstant) & .467 & .494 & & -1.311 & .198 \\
& Komite_audit & -.257 & .196 & .216 & .706 & .485 \\
& Dewan_komisaris & .018 & .026 & .119 & .102 & .919 \\
& Kepemilikan_inst & .000 & .003 & .019 & .816 & .420 \\
\hline
\end{tabular}

Dependent : abs_ut2

Sumber: Data sekunder diolah, 2019.

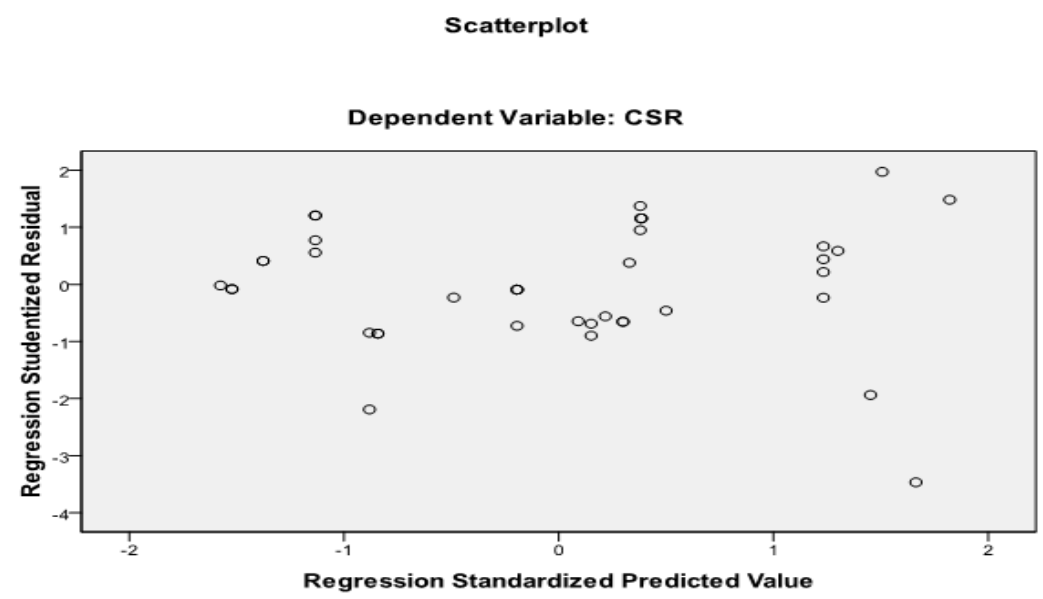

\section{Gambar 3. Hasil Uji Scatterplot}

Sumber: Data sekunder diolah, 2019.

\section{Tabel 4. Hasil Uji Autokorelasi}

Model Summary ${ }^{b}$

\begin{tabular}{lccccc}
\hline Model & $\mathrm{R}$ & R Square & Adjusted R Square & Std. Error of the Estimate & Durbin-Watson \\
\hline 1 & $.757^{\mathrm{a}}$ & .573 & .524 & .04852 & 1.820 \\
\hline
\end{tabular}

a. Predictors: (Constant), Komisaris_independen, Dewan_komisaris, Komite_audit, Kepemilikan_inst

b. Dependent Variable: CSR

Sumber: Data sekunder diolah, 2019. 
Tabel 5. Hasil Analisis Regresi Linier Berganda dan Uji Parsial

\begin{tabular}{|c|c|c|c|c|c|c|}
\hline \multicolumn{7}{|c|}{ Coefficients $^{\mathrm{a}}$} \\
\hline \multirow{2}{*}{\multicolumn{2}{|c|}{ Model }} & \multicolumn{2}{|c|}{ Unstandardized Coefficients } & \multirow{2}{*}{$\begin{array}{c}\text { Standardized Coefficients } \\
\text { Beta }\end{array}$} & \multirow[b]{2}{*}{$\mathrm{t}$} & \multirow[b]{2}{*}{ Sig. } \\
\hline & & B & Std. Error & & & \\
\hline 1 & (Constant) & .425 & .076 & & 5.628 & .000 \\
\hline & Komite_audit & -.081 & .030 & -.305 & -2.681 & .011 \\
\hline & Dewan_komisaris & .007 & .004 & .216 & 1.860 & .071 \\
\hline & Kepemilikan_inst & -.002 & .000 & -.547 & -4.259 & .000 \\
\hline & Komisaris_independen & .000 & .001 & -.098 & -.772 & .446 \\
\hline
\end{tabular}

a. Dependent Variable: CSR

Sumber: Data sekunder diolah, 2019.

\section{Analisis Regresi Linier Berganda}

Analisis regresi linier berganda dilakukan untuk mengetahui besaran serta arah dari pengaruh setiap variabel independen terhadap variabel dependen. Hasil perhitungan regresi linier berganda ditunjukkan dalam Tabel 5 .

Berdasarkan Tabel 5 dapat diformulasikan model ataupun persamaan regresi linier berganda untuk penelitian ini, yaitu:

$$
\begin{aligned}
Y= & 0,425-0,081 X_{1}+0,007 X_{2}-0,002 X_{3} \\
& +0,000 X_{4}
\end{aligned}
$$

dimana Y adalah Corporate Social Responsibility; $\mathrm{X}_{1}$ adalah Komite Audit; $\mathrm{X}_{2}$ adalah Dewan Komisaris; $\mathrm{X}_{3}$ adalah Kepemilikan Institusional; dan, $\mathrm{X}_{4}$ adalah Komisaris Independen.

Makna dari persamaan itu dijabarkan sebagai berikut. Nilai konstanta sebesar 0,425 menyatakan bahwa apabila semua variabel independen memiliki nilai konstan atau tidak berubah maka pengungkapan CSR sebesar 0,425. $\mathrm{X}_{1}$ sebesar -0,081 menyatakan bahwa Komite Audit memiliki pengaruh bersifat negatif terhadap CSR; yaitu apabila komite audit mengalami pertambahan anggota maka pengungkapan CSR mengalami penurunan, atau sebaliknya. Nilai $X_{2}$ sebesar 0,007 menyatakan Dewan Komisaris memiliki pengaruh bersifat positif terhadap CSR; yaitu apabila dewan komisaris mengalami pertambahan anggota maka pengungkapan CSR akan mengalami kenaikan, atau sebaliknya.
Selanjutnya, nilai $\mathrm{X}_{3}$ sebesar $-0,002$ menyatakan bahwa Kepemilikan Institusional memiliki pengaruh bersifat negatif terhadap CSR; yaitu apabila porsi jumlah saham dari Kepemilikan Institusional mengalami peningkatan maka pengungkapan CSR mengalami penurunan, atau sebaliknya. Nilai $\mathrm{X}_{4}$ sebesar 0,000 menyatakan Komisaris Independen relatif bisa dinyatakan tidak memiliki pengaruh terhadap CSR; yaitu apabila jumlah anggota dari tim Komisaris Independen mengalami pertambahan ataupun penurunan maka pengungkapan CSR relatif tidak mengalami perubahan.

Berdasarkan perbandingan atas nilai koefisien regresi pada persamaan regresi, maka bisa dinyatakan bahwa variabel Komite Audit $\left(b_{1}=-0,081\right)$ memiliki pengaruh paling besar terhadap perubahan pengungkapan CSR dibandingkan variabel-variabel independen lain. Di sisi lain, variabel Komisaris Independen $\left(b_{4}=0,000\right)$ dinilai memiliki pengaruh paling kecil atas perubahan pengungkapan CSR dibandingkan variabelvariabel independen yang lain.

\section{Uji Hipotesis}

Uji hipotesis mula-mula dilakukan atas pola hubungan yang bersifat parsial (uji t), dan berikutnya dilakukan atas hubungan bersifat simultan (uji F). Analisis koefisien determinasi dilakukan sebagai langkah akhir dari proses ini. 
Berdasarkan Tabel 5 bisa dilakukan identifikasi derajat signifikan atas masingmasing variabel independen terhadap variabel dependen. Tabel tersebut menunjukkan bahwa hanya dua variabel independen yang memiliki pengaruh parsial yang signifikan terhadap pengungkapan CSR, yaitu Komite Audit $\left(\mathrm{X}_{1}\right.$ $=0,011<0,05)$ dan Kepemilikan Institusional $\left(X_{3}=0,000<0,05\right)$. Dengan demikian, dinyatakan bahwa hipotesis pertama (H1) serta hipotesis ketiga (H3) dapat diterima atau dibuktikan.

Sementara itu, Tabel 5 juga menunjukkan bahwa dua variabel independen yang lain dinilai memiliki pengaruh parsial yang tidak signifikan terhadap pengungkapan CSR, yaitu Dewan Komisaris $\left(\mathrm{X}_{2}=0,071>0,05\right)$ dan Komisaris Independen $\left(\mathrm{X}_{4}=0,446>0,05\right)$. Dengan demikian, dinyatakan hipotesis kedua (H2) serta hipotesis keempat (H4) ditolak atau tidak dapat dibuktikan.

Langkah selanjutnya adalah menguji hipotesis kelima yang berkaitan dengan pengaruh simultan dari keseluruhan variabel independen terhadap variabel dependen. Tabel 6 menunjukkan bahwa nilai Sig. F sebesar 0,000 atau kurang dari 0,05 ( $\alpha$ ), atau bahwa keempat variabel independen yang dicakup dalam persamaan dari penelitian ini dinilai memiliki pengaruh simultan yang signifikan terhadap pengungkapan CSR. Dengan demikian, dinyatakan hipotesis kelima (H5) dapat diterima atau dibuktikan.

Langkah terakhir adalah melakukan analisis koefisien determinasi. Tabel 7 menunjukkan nilai koefisien determinasi $\left(\mathrm{R}^{2}\right)$ yang diperoleh adalah sebesar 0,524. Hasil ini menyatakan variabel-variabel independen yang dicakup dalam persamaan dari penelitian ini (yaitu: Komite Audit, Dewan Komisaris, Kepemilikan Institusional dan Komisaris Independen) mampu menjelaskan perubahanperubahan yang terjadi pada pengungkapan Corporate Social Responsibility sebesar $52,4 \%$; sementara sisanya sebesar $47,6 \%$ dipengaruhi oleh variabel-variabel independen lainnya yang tidak termasuk dalam persamaan, seperti kepemilikan manajerial, ukuran perusahaan, probabilitas, earning management, profil perusahaan, ataupun leverage.

\section{Tabel 6. Hasil Uji Simultan}

ANOVA $^{b}$

\begin{tabular}{|c|c|c|c|c|c|c|}
\hline \multicolumn{2}{|c|}{ Model } & Sum of Squares & df & Mean Square & $\mathrm{F}$ & Sig. \\
\hline \multirow[t]{3}{*}{1} & Regression & .111 & 4 & .028 & 11.742 & $.000^{\mathrm{a}}$ \\
\hline & Residual & .082 & 35 & .002 & & \\
\hline & Total & .193 & 39 & & & \\
\hline
\end{tabular}

a. Predictors: (Constant), Komisaris_independen, Dewan_komisaris, Komite_audit, Kepemilikan_inst

b. Dependent Variable: CSR

Sumber: Data sekunder diolah, 2019.

\section{Tabel 7. Hasil Koefisien Determinasi}

Model Summaryb

\begin{tabular}{lcccc}
\hline Model & $\mathrm{R}$ & $\mathrm{R}$ Square & Adjusted R Square & Std. Error of the Estimate \\
\hline 1 & $.757^{\mathrm{a}}$ & .573 & .524 & .04852 \\
\hline
\end{tabular}

a. Predictors: (Constant), Komisaris_independen, Dewan_komisaris, Komite_audit, Kepemilikan_inst

b. Dependent Variable: CSR

Sumber: Data sekunder diolah, 2019. 


\section{Pembahasan}

Pada bagian ini dilakukan pembahasan atas hasil-hasil penelitian ini dikaitkan dengan hasil-hasil penelitian terdahulu.

\section{Pengaruh Komite Audit terhadap Peng- ungkapan Corporate Social Responsibility (CSR)}

Komite audit dibuktikan melalui penelitian ini bahwa memiliki pengaruh negatif dan signifikan terhadap Corporate Social Responsibility. Hasil ini sejalan dengan hasil penelitian Wiyuda dan Pramono (2017) yang menemukan adanya pengaruh negatif oleh komite audit terhadap Corporate Social Responsibility. Hasil penelitian ini menunjukkan bahwa semakin sedikit jumlah anggota audit, maka akan lebih baik pengaruhnya terhadap luas pengungkapan Corporate Social Responsibility.

Namun demikian, hasil penelitian ini tidak mendukung hasil penelitian Untoro dan Zulaikha (2013) yang menunjukkan bahwa komite audit tidak berpengaruh terhadap luas pengungkapan Corporate Social Responsibility. Penelitian ini juga bertolak belakang dengan hasil empiris yang diperoleh Fatimah et al. (2016) bahwa komite audit berpengaruh positif atas Corporate Social Responsibility.

\section{Pengaruh Dewan Komisaris terhadap Pengungkapan Corporate Social Responsi- bility (CSR)}

Hasil penelitian ini membuktikan bahwa dewan komisaris terbukti berpengaruh secara positif tetapi tidak signifikan terhadap Corporate Social Responsibility. Hal ini sejalan dengan hasil penelitian Paramita dan Marsono (2014) yang menemukan pengaruh dewan komisaris terhadap Corporate Social Responsibility dilihat dari jumlah dewan, bahwa semakin banyak jumlah anggota dari dewan komisaris perusahaan maka tingkat pengendalian dan pengambilan keputusan yang terjadi semakin tinggi. Pada perusahaanperusahaan yang menjadi obyek penelitian ini, rata-rata jumlah dewan komisaris tergolong rendah.

Hasil penelitian ini berbeda dengan hasil penelitian Ramadhaningsih dan Utama (2013) yang menemukan bahwa dewan komisaris berpengaruh negatif dan tidak signifikan terhadap pengungkapan CSR. Hasil penelitian ini juga tidak sejalan dengan penelitian yang dilakukan oleh Hutapea dan Malau (2018) yang memperoleh hasil bahwa dewan komisaris berpengaruh positif dan bersifat signifikan terhadap Corporate Social Responsibility.

\section{Pengaruh Kepemilikan Institusional terhadap Pengungkapan Corporate Social Responsibility (CSR)}

Hasil penelitian ini mendukung studi milik Prastuti dan Budiasih (2015), yaitu bahwa kepemilikan institusional memiliki pengaruh negatif yang signifikan terhadap CSR. Sebaliknya, hasil penelitian ini memberi bukti yang tidak sejalan dengan hasil penelitian Wiyuda dan Pramono (2017) yang menemukan bahwa kepemilikan institusional memiliki pengaruh yang tidak signifikan terhadap CSR.

Hal tersebut terjadi karena rata-rata kepemilikan institusional dalam perusahaanperusahaan yang menjadi sampel penelitian ini adalah saham mayoritas. Kondisi ini menyebabkan kepentingan saham minoritas akan diabaikan karena investor institusional mayoritas cenderung berkompromi dengan pihak manajemen. Karenanya apabila proporsi dari jumlah kepemilikan saham oleh pihak investor institusional mengalami kenaikan, maka luas pengungkapan dari Corporate Social Responsibility akan mengalami penurunan. 
Pengaruh Komisaris Independen terhadap Pengungkapan Corporate Social Responsibility (CSR)

Hasil penelitian ini sejalan dengan studi Paramita dan Marsono (2014) yang menemukan adanya kemungkinan pihak komisaris independen tidak mempengaruhi pengambilan keputusan terkait pengungkapan CS karena tidak terlibat di dalam operasional rutin perusahaan. Hasil empiris milik peneliti tersebut memunculkan argumen bahwa level komisaris independen tidak mempunyai pengaruh yang signifikan terhadap pengungkapan Corporate Social Responsibility.

Namun demikian, penelitian ini memberikan hasil berbeda dengan yang ditunjukkan oleh studi empiris milik Nugroho (2016) yang menemukan bahwa komisaris independen berpengaruh secara signifikan terhadap pengungkapan Corporate Social Responsibility. Hasil-hasil yang berbeda ini memunculkan gap yang memerlukan pembuktian lebih banyak dari riset-riset yang akan datang, sehingga bisa diperoleh konklusi yang kuat mengenai pola hubungan antara jumlah komisaris independen di dalam perusahaan dan keluasan pengungkapan CSR.

\section{SIMPULAN}

Berdasarkan hasil penelitian yang diperoleh maka bisa dinyatakan beberapa kesimpulan. Pertama, komite audit serta kepemilikan institusional teridentifikasi secara parsial berpengaruh secara negatif dan signifikan terhadap Corporate Social Responsibility pada perusahaan sub sektor transportasi yang terdaftar di Bursa Efek Indonesia dalam periode 2014-2018. Kedua, dewan komisaris dan komisaris independen dibuktikan tidak berpengaruh secara signifikan terhadap Corporate Social Responsibility pada obyek penelitian. Terakhir, komite audit, dewan komisaris, kepemilikan institusional dan komisaris independen terbukti ber- pengaruh signifikan secara simultan terhadap Corporate Social Responsibility.

Berdasarkan sejumlah kesimpulan tersebut, direkomendasikan bagi para peneliti berikutnya agar menggunakan variabelvariabel lain yang tidak dicakup dalam model penelitian ini, seperti nilai perusahaan. Hal ini dikarenakan aktivitas CSR yang dilakukan perusahaan turut memberikan nilai bagi perusahaan. Selain itu, variabel independen lain yang bisa dihubungkan dengan aktivitas CSR adalah ukuran perusahaan, karena umumnya Corporate Social Responsibility dilakukan oleh perusahaan berskala besar.

\section{REFERENSI}

Amanti, L. 2012. Pengaruh Good Corporate Governance terhadap Nilai Perusahaan dengan Pengungkapan Corporate Social Responsibility sebagai Variabel Pemoderasi pada Perusahaan Rokok yang Terdaftar di Bursa Efek Indonesia. Undergraduate Thesis. Surabaya: Universitas Negeri Surabaya.

Bradbury, M.E., Mak, Y.T. \& Tan, S.M. 2004. Board Characteristics, Audit Committee Characteristics, and Abnormal Accruals. Working Paper. United New Zealand and National University of Singapore.

Coller, P. \& Gregory, A. 1999. Audit Committee Activity and Agency Cost. Journal of Accounting and Public Policy. 18(4-5): 311-332.

Fatimah, S., Makhdalena \& Trisnawati, F. 2016. Pengaruh Komisaris Independen dan Komite Audit terhadap Pengungkapan Corporate Social Responsibility Perusahaan Pertambangan di Bursa Efek Indonesia Periode 2012 s.d 2014. Jurnal Online Mahasiswa, Fakultas Keguruan dan Ilmu Pendidikan, Universitas Riau. 3(2): 1-11.

Hasan, I. 2004. Analisis Data Penelitian dengan Statistik. Yogyakarta: PT. Bumi Aksara. 
Hutapea, H.D. \& Malau, E.L. 2018. Pengaruh Praktek Good Corporate Governance (GCG) terhadap Pengungkapan Corporate Social Responsibility (Studi Kasus Perusahaan Perbankan yang Terdaftar di Bursa Efek Indonesia). Jurnal Ilmiah Sky Land Sea. 2(2): 278-291.

Keraf, A.S. 1998. Etika Bisnis: Tuntunan dan Relevansinya. Yogyakarta: Kanisius.

Nilasari, E. 2015. Pengaruh Profitabilitas, Kepemilikan Institusional, Kepemilikan Asing dan Size terhadap CSR Disclosure Perusahaan Tambang (Mining Sector) yang melakukan Listing di Bursa Efek Indonesia Tahun 2010-2012. Skripsi. Semarang: Fakultas Ekonomi dan Bisnis Universitas Dian Nuswantoro.

Nugroho, I.A. 2016. Pengaruh Karakteristik Perusahaan dan Corporate Governance terhadap Pengungkapan Corporate Social Responsibility pada Perusahaan Manufaktur di BEI Tahun 2010-2014. Skripsi. Surakarta: Fakultas Ekonomi dan Bisnis Universitas Muhammadiyah Surakarta.

Paramita, A.D. \& Marsono. 2014. Pengaruh Karakteristik Corporate Governance terhadap Luas Pengungkapan Corporate Social Responsibility. Diponegoro Journal of Accounting, 3(1): 1-15.

Pasaribu, R., Kowanda, D. \& Kurniawan, D. 2015. Pengaruh Earning Management dan Mekanisme Good Corporate Governance terhadap Pengungkapan Corporate Social Responsibility. Jurnal Riset Manajemen \& Bisnis. 10(2): 97 121.

Prastuti, N.K.K. \& Budiasih, I.G.A.N. 2015. Pengaruh Good Corporate Governance pada Nilai Perusahaan dengan Moderasi Corporate Social Responsibility. EJurnal Akuntansi Universitas Udayana. 13(1): 114-129.

Rachmad, A.A. 2013. Pengaruh Penerapan Corporate Governance Berbasis Karak teristik Manajerial pada Kinerja Perusahaan Manufaktur. E-Jurnal Akuntansi Universitas Udayana, 2(3): 678-696.
Ramadhaningsih, A. \& Utama, I.M.K. 2013. Pengaruh Indikator Good Corporate Governance dan Profitabilitas pada Pengungkapan Corporate Social Responsibility. E-Jurnal Akuntansi Universitas Udayana. 3(2): 368-386.

Rustiarini, N.W. 2010. Pengaruh Corporate Governance pada Hubungan Corporate Social Responsibility dan Nilai Perusahaan. Prosiding. Simposium Nasional Akuntansi (SNA) XIII. Purwokerto: Universitas Jenderal Soedirman Purwokerto.

Sanjaya, O., Taufik, T. \& Azhar, A.L 2014. Pengaruh Good Corporate Governance, Profitabilitas, dan Ukuran Perusahaan terhadap Pengungkapan Tanggung Jawab Sosial Perusahaan pada Perusahaan Real Estate dan Property yang Terdaftar di Bursa Efek Indonesia (2010-2011). Jurnal Online Mahasiswa Fakultas Ekonomi, Universitas Riau. 1(1): 1-15

Sari, A.R., Sutrisno \& Sukoharsono, E.G. 2013. Pengaruh Kepemilikan Institusional, Komposisi Dewan Komisaris, Kinerja Perusahaan terhadap Luas Pengungkapan Corporate Social Responsibility di dalam Sustainability Report pada Perusahaan Manufaktur yang Terdaftar di BEI. Jurnal Aplikasi Manajemen. 11(3): 481-491.

Sayekti, Y. \& Wondabio, L.S. 2007. Pengaruh CSR Disclosure terhadap Earning Response Coefficient (Suatu Studi Empiris pada Perusahaan yang Terdaftar di Bursa Efek Indonesia). Makalah. Simposium Nasional Akuntansi X. Makassar: Universitas Hasanuddin.

Setyarini, Y. \& Paramitha, M. 2011. Pengaruh Mekanisme Good Corporate Governance terhadap Corporate Social Responsibility. Jurnal Kewirausahaan. 5(2): 10-17.

Shleifer, A. \& Vishny, R.W. 1986. Large Shareholders and Corporate Control. Journal of Political Economy. 94(3): 461-488. 
Siagian, M. \& Suriadi, A. 2010. Tanggung Jawab Sosial Perusahaan CSR Perspektif Pekerjaan Sosial. Medan: FISIP USU Press.

Terzaghi, M.T. 2012. Pengaruh Earing Management dan Mekanisme Corporate Governance terhadap Pengungkapan Tanggung Jawab Sosial Perusahaan Manufaktur yang Terdaftar di Bursa Efek Indonesia. Jurnal Ekonomi dan Informasi Akuntansi (Jenius). 2(1): 31-47.

Untoro, D.A. \& Zulaikha. 2013. Pengaruh Karakteristik Good Corporate Governance (GCG) terhadap Luas Pengungkapan Corporate Social Responsibility (CSR) di Indonesia. Diponegoro Journal of Accounting. 2(2): 1-11.

Waryanto. 2010. Pengaruh Karakteristik Good Corporate Governance (GCG) terhadap Luas Pengungkapan Corporate Social Responsibility (CSR) di Indonesia. Skripsi. Semarang: Fakultas Ekonomi Universitas Diponegoro.
Wiyuda, A. \& Pramono, H. 2017. Pengaruh Good Corporare Governance, Karakteristik Perusahaan terhadap Luas Pengungkapan Corporate Social Responsibility pada Perusahaan Terdaftar di BEI. Jurnal Ilmiah Akuntansi. 15(1): 12-25.

Yusran, I., Ariqah, R., Kristanti, F.T. \& Aminah, W. 2018. Pengaruh Indikator Good Corporate Governance terhadap Corporate Responsibility Disclosure (Studi pada Perusahaan Manufaktur yang Terdaftar di Bursa Efek Indonesia Periode 2011-2016). E-Proceeding of Management. 5(1): 621-627. 